\title{
Les nourritures de l'identité. Commensalité et pratiques culinaires festives dans les Alpes de Méditerranée
}

\section{Robert Castellana}

\section{OpenEdition}

Journals

Édition électronique

URL : https://journals.openedition.org/tc/396

DOI : $10.4000 /$ tc.396

ISSN : 1952-420X

Éditeur

Éditions de l'EHESS

Édition imprimée

Date de publication : 1 avril 1999

ISSN : 0248-6016

Référence électronique

Robert Castellana, «Les nourritures de l'identité. Commensalité et pratiques culinaires festives dans les Alpes de Méditerranée», Techniques \& Culture [En ligne], 31-32 | 1999, mis en ligne le 26 octobre 2005, consulté le 29 septembre 2022. URL : http://journals.openedition.org/tc/396 ; DOI : https:// doi.org/10.4000/tc.396

Ce document a été généré automatiquement le 29 septembre 2022

Tous droits réservés 
Les nourritures de l'identité. Commensalité et pratiques culinaires festives dans les Alpes de Méditerranée

Robert Castellana 